ACTA AGROBOTANICA

Vol. 58, z. 12005

s. 7378

\title{
Races of Pyrenophora tritici-repentis in the Czech Republic
}

\section{ŠÁROVÁ J., HANZALOVÁ A., BARTOŠ P.}

\author{
Research Institute of Crop Production, Prague 6 Ruzyně, Drnovská 507, 161 06, \\ Czech Republic, e mail: sarova@vurv.cz
}

(Received: 15.03.2005)

\begin{abstract}
Summary
Pyrenophora tritici-repentis, causal agent of tan spot, is one of the most important wheat leaf spot pathogens worldwide. The race structure of $P$. tritici-repentis isolates obtained from wheat (except one from noncereal grass species) in the Czech Republic was studied. The 86 monosporic isolates of $P$. tritici-repentis originated from different parts of the Czech Republic were grouped into five known races based on necrosis/chlorosis induction on standard differentials (Katepwa, Glenlea, 6B365, Salamouni). The isolates recovered from wheat were races 1, 2 and 4. Race 1 was the most frequent (50\%), races 2 and 4 were found rarely (3\% and 5\% respectively). The isolate of $P$. tritici-repentis recovered from noncereal grass species was determined as race 4 which seems to be typical for noncereal hosts. The reaction of 30 isolates $(42 \%)$ was difficult to be compared to reactions of so far identified P. tritici-repentis races. They have to be tested again on additional wheat genotypes.
\end{abstract}

Key words: Pyrenophora tritici repentis, races

\section{INTRODUCTION}

The fungal foliar pathogen Pyrenophora tritici-repentis (Died.) Drechs. (anam. Drechslera tritici-repentis (Died.) Shoem.) is the causal agent of tan spot of wheat. This disease is one of the most important diseases caused by wheat leaf spot pathogens worldwide. In the Czech Republic P. tritici-repentis has been determined more and more often since about 1998 (Š́árová et al., 2003). Tan spot has become a new problem not only in the Czech Republic but in many European countries too ( $\mathrm{Z}$ a morski and Schollenberger, 1994; Bakonyi et al., 1998; Mikhailova and Prigorovskaya, 2000), in the last few years. Control of tan spot includes using of fungicides, crop management, biological control and resistant cultivars. The development of resistant cultivars to Pyrenophora tritici-repentis is thought to be the best way to reduce yield losses caused by tan spot (De Wolf et al., 1998). 
Study of variability of pathogen population is necessary for development of durably resistant cultivars to the disease. Two qualitative types of symptoms, tan necrosis (nec+) and extensive chlorosis (chl+), induced by $P$. tritici-repentis were identified (Lamari and Bernier, 1989a; Lamari et al. 1991). Based on these two types of symptoms, nowadays Pyrenophora tritici-repentis isolates are separated into 8 races which are grouped according to their virulence/avirulence combination to cultivars/lines used as a differential set (Lamari and Bernier, 1989b; Lamari et al., 1991; Lamari et al., 1995; Ali and Franc1, 1998, 1999, 2002; Ali et al., 2002; Lamari et al., 2002, Strelkov et al., 2002). The differential set have been modified since detection of three new races 6, 7, 8 in 2002 and new differential lines have been tested (Lamari et al., 2002; Ali and Francl, 2003).

Pyrenophora tritici-repentis is known to have highly specialized relationships with its host. Compatibility between the host and the pathogen was shown to be mediated by host-specific toxins, produced by different isolates of the pathogen. So far four host-specific toxins were characterized, one necrosis inducing toxin Ptr Tox A, two chlorosis inducing toxins Ptr Tox B and Ptr Tox C and one necrosis and chlorosis inducing toxin Ptr ToxD (Ballance et al., 1989; Brown and Hunger, 1993; Orolaza et al., 1995; Ali et al., 2002).

The aim of our study was to characterize race structure of Pyrenophora triticirepentis population on wheat in the Czech Republic.

\section{MATERIALS AND METHODS}

The race structure of $P$. tritici-repentis population on wheat has been studied in the Czech Republic since 2001. Only 5 P. tritici-repentis races were known at that time. Four standard differential lines described in Tab. 1 were used for determination of the races. The reaction of 86 monosporic $P$. tritici-repentis isolates from different parts of the Czech Republic to a differential set was analyzed.

Tab. 1. Pyrenophora tritici repentis races, designation, and symptoms on wheat differential lines

(De Wolf et al. 1998)

\begin{tabular}{llllll}
\hline \multirow{2}{*}{ Line } & \multicolumn{5}{c}{ Race } \\
\cline { 2 - 6 } Katepwa & 1 & 2 & 3 & 4 & 5 \\
Glenlea & $\mathrm{S}(\mathrm{N})$ & $\mathrm{S}(\mathrm{N})$ & $\mathrm{R}$ & $\mathrm{R}$ & $\mathrm{S}(\mathrm{C})$ \\
6B365 & $\mathrm{S}(\mathrm{N})$ & $\mathrm{S}(\mathrm{N})$ & $\mathrm{R}$ & $\mathrm{R}$ & $\mathrm{R}$ \\
Salamouni & $\mathrm{S}(\mathrm{C})$ & $\mathrm{R}$ & $\mathrm{S}(\mathrm{C})$ & $\mathrm{R}$ & $\mathrm{R}$ \\
& $\mathrm{R}$ & $\mathrm{R}$ & $\mathrm{R}$ & $\mathrm{R}$ & $\mathrm{R}$ \\
\hline
\end{tabular}

$\mathrm{S}=$ susceptible, $\mathrm{R}=$ resistant $\mathrm{N}$ necrosis, $\mathrm{C}$ chlorosis 
Inoculum was prepared using a procedure described by Evans et al. (1996) and Ali et Francl (2001) with some modifications. P. tritici-repentis isolates were grown on PCA (potato-carrot agar) (Anonymus, 1990). After about 4 days of incubation at $22^{\circ} \mathrm{C}$ in the dark the Petri dishes were flooded with sterilized distilled water and the mycelium was scraped and excess water was decanted. Thereafter, the Petri dishes were incubated $24 \mathrm{~h}$ in light at $22^{\circ} \mathrm{C}$ to induce conidiophores production and $24 \mathrm{~h}$ in dark at $16^{\circ} \mathrm{C}$ to induce conidia production. Then the dishes were flooded with sterilized distilled water $(30 \mathrm{ml})$ with Tween $20(0,08 \mathrm{ml} / 100 \mathrm{ml})$, conidia were dislodged with inoculating needle and conidial suspension was decanted and adjusted to cca 3000 spores $/ \mathrm{ml}$.

Seedlings of the differential set were inoculated at the two-leaf stage by spraying of the conidial suspension until run off. The inoculated seedlings in plastic pots were covered by glass tubes for 24 hours to keep higher humidity after inoculation, the temperature in the greenhouse was about $20^{\circ} \mathrm{C}$. Reaction of the differential cultivars/ lines was rated on a 1-5 qualitative scale (La mari and B ernier, 1989a) 7-10 days after inoculation.

\section{RESULTS AND DISCUSSION}

Although tan spot seems to be one of the most important diseases from a complex of necrotrophic leaf spot diseases of wheat in Europe there is still no published report about race structure of Pyrenophora tritici-repentis in this area. Our study was one of the first dealing with this topic in European countries.

The reactions of 86 monosporic $P$. tritici-repentis isolates coming from different parts of the Czech Republic to the differential set were analyzed. Race 1 was prevalent beeing detected 23 times (50\%). Race 2 was found out only 3 times (3\%)and 4 isolates $(5 \%)$ belonged to race 4 (Fig. 1). The reaction of 30 isolates $(42 \%)$ was difficult to be compared to reactions of so far identified $P$. tritici-repentis races. It will be necessary to repeat these experiments with novel differential lines (L a m a ri et al., 2002; Ali and Franc1, 2003) to confirm possible new races.

Variability of $P$. tritici-repentis population was studied in different parts of the world. Race 1 is predominant in North America (Lamari and Bernier, 1989b; Lamari et al., 1998; Ali et Franc1, 1998). Race 1 was prevalent in western Canada in the years 1984-1987, races 2, 3, 4 were recovered rarely (La mari and Berni e r, 1989b). Races 1 and 2 were predominant in western Canada in the years 19901994, isolates of races 3 and 4 were found at low levels only in some years, no isolates of race 5 were identified (Lamari et al., 1998). Race 2 have been more and more common in North America since nineties and its frequency would be expected to be similar to that of race 1. Race 2 predominated in southeast Asia in 2000-2002 too (Mercado et al., 2002). For the first time race 5 was determined in the isolates from eastern Algeria (La mari et al., 1995) and it was reported on durum wheat in North America as well (Ali et al., 1999). The other Algerian isolate was classified as a new race 6 (Strelkov et al., 2002). Race 7 was reported in Argentina (Ali et al., 2002) and race 8 in Brazil (Ali et Franc1, 2002). 
Fig. 1. Distribution of Pyrenophora tritici repentis races in the Czech Republic (86 tested isolates)

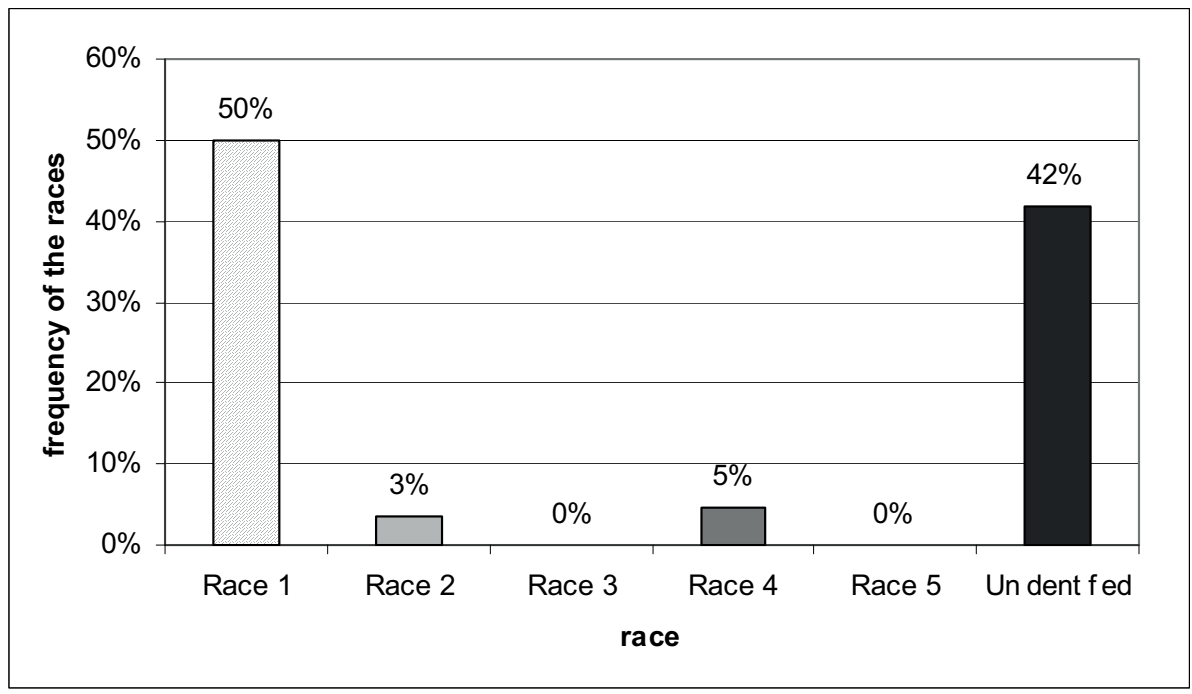

Population race structure of $P$. tritici-repentis prevalent on wheat and noncereal grasses in the Great Plains was studied (Ali et Franc1, 2003). The isolates recovered from wheat were races 1 (more than 90\%), 2 and 4 (rarely) while those from durum were races 1 and 5. Isolates from noncereal grasses were all race 4, except for two isolates of race 1 . It confirms the finding that race 4 is typical for noncereal grasses. In our study one isolate from a noncereal grass species was determinated as race 4 too.

\section{Acknowledgements}

This study was supported by the Grant Agency of the Czech Republic (project No. 521/00/0226), Ministry of Education, Youth and Sports (project No. 44).

\section{REFERENCES}

Ali S., Francl L. J. 1998. Race structure of Pyrenophora tritici repentis isolated from wheat and grasses in the US Great Plains. Phytopathology, 88: S114.

Ali S., Francl L. J. 1999. Races of Pyrenophora tritici repentis on durum in the northern Great Plains of the US. Phytopathology, 89: S2.

Ali S., Francl L. J. 2001. Recovery of Pyrenophora tritici repentis from barley and reaction of 12 cultivars to five races and two host specific toxins. Plant Disease, 85(6): 580584.

Ali S., Francl L. J. 2002. A new race of P. tritici repentis from Brazil. Plant Disease, 86:1050.

Ali S., Francl L. J. 2003. Population race structure of Pyrenophora tritici repentis preva lent on wheat and noncereal grasses in the Great Plains. Plant Disease, 87(4): 418422. 
Ali S., Francl L. J., De Wolf, 1999. First report of Pyrenophora tritici repentis from North America. Plant Disease, 83:591.

Ali S., Ling H., Meinhardt S., Francl L. J., 2002. A new race of P. tritici repentis that produces a host selective toxin. Phytopathology, 92: S3.

A nonymus, 1990: CBS List of cultures. Fungi and Yests. $32^{\text {nd }}$ edition. 508 p., Baarn Delft.

Bakonyi J., A ponyi I., Fischl G., 1998. Diseases caused by Bipolaris sorokiniana and Drechslera tritici repentis in Hungary. In: Duveiller E., Dubin H. J., Reeves J. et McNab A. [eds.]: Helminthosporium Blights of Wheat: Spot Blotch and Tan Spot. Mexico, El Batan: 8087.

Ballance G. M., Lamari L., Bernier C. C., 1989. Purification and characterization of a host selective necrosis toxin from Pyrenophora tritici repentis. Physiological and Mo lecular Plant Pathology, 35: 203213.

B rown D. A., Hunger R. M., 1993. Production of a chlorosis inducing, host specific, low molecular weight toxin by isolates of Pyrenophora tritici repentis, cause of tan spot of wheat. J. Phytopathol., 137: 221232.

De Wolf E. D., Effertz R. J., Ali S., Francl L. J., 1998. Vistas of tan spot research. Canadian Journal of Plant Pathology, 20(4): 349370.

Evans C. K., Hunger R. M., Siegerist W. C., 1996. Inoculum density and infection efficiency of conidia and conidiophores of isolates of Pyrenophora tritici repentis. Plant Disease, 80(5): 505512.

Lamari L., Bernier C. C., 1989a. Evaluation of wheat lines and cultivars to tan spot [Pyre nophora tritici repentis] based on lesion type. Can. J. Plant Pathol, 11:49 56.

Lamari L., Bernier C. C., 1989b. Virulence of isolates of Pyrenophora tritici repentis: on 11 wheat cultivars and cytology of the differential host reactions. Can. J. Plant Pathol., 11:284 290 .

Lamari L., Bernier C. C., Smith R. B., 1991. Wheat genotypes that develop both tan necrosis and extensive chlorosis in response to isolates of Pyrenophora tritici repentis. Plant Disease, 75: 121122.

Lamari L., Gilbert J., Tekauz A., 1998. Race differentiation in Pyrenophora tritici repentis and survey of physiologic variation in western Canada. Can. J. Plant Pathol., 20(4): 396400.

Lamari L., Sayoud R., B oulif M., Bernier C. C., 1995. Identification of a new race in Pyrenophora tritici repentis: implication for the current pathotype classification sys tem. Can. J. Plant Pathol., 17: 312318.

Lamari L., Strelkov S. E., Yahy a ou i A., Orabi J., Smith R. B., 2002. The identifi cation of two new races of Pyrenophora tritici repentis from the host center of diversity confirms a one to one relationship in tan spot of wheat. Phytopathology, 93(4): 391396.

Mercado D., Renard M. E., Duveiller E., Maraite H., 2002. Recent leaf blights surveys in southeast Asia and characterisation of Drechslera tritici repentis isolates. In: $4^{\text {th }}$ International Wheat Tan Spot and Spot Blotch Workshop, Bemidji, July 2124 , 2002, 24.

Mikhailova L. A., Prigorovskaya T. I., 2000. Yellow leaf spot of wheat Pyrenophora tritici repentis. Mikologia i Fitopatologia, 34(1): 716.

Orolaza N. P., Lamari L., B allance G. M., 1995. Evidence of a host specific chlorosis toxin from Pyrenophora tritici repentis, the causal agent of tan spot of wheat. Phytopa thology, 85(10): 12821287. 
Strelkov S. E., Lamari L., Sayoud R., S mith R. B., 2002. Comparative virulence of chlorosis inducing races of Pyrenophora tritici repentis. Canadian Journal of Plant Pathology, 24: 2935.

Šárová J., Hanzalová A., B artoš P., 2003. Incidence of wheat leaf spot pathogens in the Czech Republic. Cereal Research Communication, 31: 145151.

Zamorski C., Schollenberger M., 1994. The occurence of tan spot of wheat and tritica le in Poland. Genetica Polonica, 35B: 375378.

\section{Streszczenie}

Badano strukturę populacji $P$. tritici-repentis pod kątem występowania ras patogena. W analizie uwzględniono 86 jednozarodnikowych izolatów pochodzących z różnych regionów Czech a uzyskanych z pszenicy (85) i traw (1). Bazując na reakcji genotypów zestawu testowego (Katepwa, Glenlea, 6B365, Salamouni) stwierdzono występowanie trzech ras: 1, 2, i 4. Liczebnie dominującą była rasa 1, którą reprezentowało 50\% izolatów. Rasa 2 i 4 stanowiła jedynie 3\% i 5\% populacji. Największą grupę (42\%) stanowiły izolaty dla których reakcja roślin zestawu testowego uniemożliwiała jednoznaczną identyfikację jednej z 5 określonych ras patogena. Konieczne są dalsze badania z uwzględnieniem dodatkowych genotypów umożliwiających bardziej precyzyjną charakterystykę populacji $P$. tritici-repentis. 